\title{
SYSTEMIC THEORY, MERITOCRACY AND THE DEPOLITICIZATION OF INSTITUTIONS: THOUGHTS ON THE NORMATIVE ROUTE OF CONTEMPORARY LIBERAL POLITICAL THEORY - AN ESSAY
}

\author{
[TEORIA SISTÊMICA, MERITOCRACIA E A DESPOLITIZAÇÃO DAS INSTITUIÇÕES: REFLEXÕES \\ SOBRE O CAMINHO NORMATIVO DA TEORIA POLÍTICA LIBERAL CONTEMPORÂNEA - UM ENSAIO]
}

Leno Francisco Danner *

Fundação Universidade Federal de Rondônia, Brasil Agemir Bavaresco ** Pontifícia Universidade Católica do Rio Grande do Sul, Brasil Fernando Danner ***

Fundação Universidade Federal de Rondônia, Brasil

\begin{abstract}
: in this paper, we criticize the depoliticization of Western modernization by liberal political theories through the correlation between systemic institutional theory and meritocracy, which is based on the idea of strong individualism with regard to the understanding and the legitimation of social evolution, as well as the logical-technical constitution of social systems. Thus, according to liberal political theories, meritocracy defines social stratification and even systemic institutional evolution throughout time, due to the fact that it is the only political possibility from the viewpoint of a technical-logical understanding of social systems, which implies the delegitimation of an inclusive democratic political praxis concerning the structuring and evolution of such social systems. Our central argument is that a proper political comprehension of Western modernization needs to overcome both the technical-logical understanding of institutions and meritocracy as bases for the comprehension and legitimation of political praxis, institutional evolution, political reformism and social rights. The notions of political democracy and social
\end{abstract}

ReSumo: neste artigo, criticamos a despolitização da modernização ocidental, feita por teorias liberais a partir da correlação entre teoria institucional sistêmica e meritocracia, correlação esta que é baseada em um individualismo forte em termos de entendimento e de legitimação da evolução social, bem como no sentido lógico-técnico dos sistemas sociais. Assim, de acordo com as teorias políticas liberais, a meritocracia define a estratificação social e mesmo a evolução institucional sistêmica ao longo do tempo, pelo fato de que ela é a única possibilidade política desde um entendimento lógico-técnico dos sistemas sociais, o que implica a deslegitimação de uma práxis política democrática inclusiva no que se refere à estruturação e à evolução dos próprios sistemas sociais. Nosso argumento central é o de que uma compreensão política da modernização ocidental necessita superar seja a compreensão institucional sistêmica, seja a meritocracia como bases do entendimento e da legitimação da práxis política, da evolução institucional, do reformismo político e dos direitos sociais. As noções de democracia política e de justiça

* Professor de Filosofia e de Sociologia no Departamento de Filosofia da Fundação Universidade Federal de Rondônia. ** Doutor em Filosofia (Université de Paris I - Pantheon Sorbonne). Professor de Ética e Filosofia Política no Departamento de Filosofia e no Programa de Pós-Graduação em Filosofia da Pontifícia Universidade Católica do Rio Grande do Sul (PUCRS). *** Doutor em Filosofia (PUCRS). Professor de Filosofia no Departamento de Filosofia da Universidade Federal de Rondônia (UNIR). 
justice, therefore, must be considered through the refusal of systemic theory and of strong individualism - both assumed by contemporary liberal political theories.

KEYwORDS: Western modernization. Political

12 liberalism. Social systems. Meritocracy. Political praxis. social, portanto, devem ser pensadas e buscadas a partir da recusa da teoria sistêmica e do individualismo forte propugnados por teorias políticas liberais contemporâneas.

Palavras-Chave: Modernização ocidental. Liberalismo político. Sistemas sociais. Meritocracia. Práxis política.

\section{INTRODUCTION}

$\mathrm{W}$ estern modernization is a very current and dramatic normative-political question, as we can see in the current social-economic crisis, which affects developed and underdeveloped societies alike around the world. Indeed, its normative-political understanding, which is not a political consensus - far from it, as a matter of fact -, ceaselessly streamlines social-political clashes and theoretical developments concerning the emergence, present situation and future of Western modernization. When we talk about social inequalities, or State, or capitalism, or even liberty and equality in modern societies, we are talking about such concept of Western modernization, both in a normative sense and in a sociological sense. Our starting point - in this paper and in contemporary political theory - is to problematize exactly the fact that there is not an objective and pure notion of Western modernization that can enable consensual philosophical-sociological approaches, nor is there a political praxis about the cultural specificities, psychosocial pathologies, political reformism, status quo and economic constitution of the Western modernization. In other words, there is not a scientific comprehension (in the Positivist style) of Western modernization that is nonpolitical, so Western modernization is first and foremost a political notion, a political comprehension that depends on the hegemony of social forces, of their confronts throughout time.

In this paper, we want to criticize the liberal political comprehension of Western modernization that is based on two intertwined normative points, namely: the systemic theoretical analysis concerning the understanding of Western modernization, which puts technical institutions as the basis for the comprehension and streamlining of Western modernization, and meritocracy as the basis for the status quo in modern societies characterized by the individualization and anonimization of social subjects. Our central point is that the correlation between systemic theory and meritocracy, institutionalism and individualism leads to the depoliticization of the structuring of social systems, as well as to the depoliticization of meritocracy as a basis for the socially binding status $q u o$, in a way that delegitimizes both an inclusive democratic political praxis regarding the constitution and evolution of social systems, and a refusal of meritocracy as a basis for social stratification and redistributive policies. Then, a liberal comprehension of Western modernization conceives political democracy and social justice through a systemic institutional enclosure concerning democratic political participation, and through a pure and simple notion of meritocracy that establishes only one normative route to think and to act about political democracy and social justice in modern societies: such route is characterized by the correlation and mutual support between systemic institutional closure and meritocracy as normative-political bases for all projects of political reformism and redistributive policies, defining Western 
modernization as a material process based on the depoliticization of social clashes through a strong emphasis on individualism and on the technical-logical constitution of social systems as the motto of social stratification and social evolution, as the basis for political praxis.

We are going to argue that such correlation between systemic institutional theory and meritocracy can be perceived directly in contemporary conservative liberalism (in authors such as Friedrich Hayek, Milton Friedman and Robert Nozick) and indirectly in the political theory of the New Left (in Jürgen Habermas and Anthony Giddens, for instance), - which is very surprising. Indeed, it is so due to the fact that one important aspect of contemporary left theory is a shared theoretical-political standpoint with conservative liberalism, i.e. the systemic comprehension of modern institutions - for instance the bureaucratic-administrative State of the former and the capitalist market of the latter -, although with different conclusions - despite the intention of the left of opposing and facing conservative liberalism by offering an alternative theoreticalpolitical project on the comprehension, past and future of Western modernization. On the one hand, conservative liberalism comprehends the social constitution and evolution based on the division and individualization of society into particularized and closed institutions or social systems - especially the market. The market - as a technicallogical sphere, as a non-political and non-normative arena - is self-referential and selfsubsisting in terms of politics and social normativity, streamlined only by meritocracy, in the process defining a kind of social evolution that is spontaneous and individualized, in the sense that each individual - with no messianic self-consciousness or special wisdom - looks out for his own interests and as consequence contributes to social evolution as a whole - here there is nothing political involved, only strategic, technical. Then social institutions evolve from a spontaneous process marked by the technical-logical self-development of social systems over time, a spontaneous process that is determined only by meritocracy, not by political-normative principles and practices, nor by social classes as macro social subjects with a political basis. In the understanding of contemporary conservative liberalism, Western modernization loses its political-normative constitution, legitimation and evolution, becoming a technicallogical sphere, matter and evolutionary process that does not admit political-normative intervention in the market, since the status quo - laissez-faire and meritocracy are sufficient to allow for a fair social evolution, a legitimate social stratification and a corresponding individual distribution of social goods.

On the other hand, when Habermas and Giddens conceive Western modernization as a process of systemic institutional self-differentiation, selfreferentiality and self-subsistence, they must accept the depoliticization and the nonnormative constitution of the social systems, which become very individualized, technical-logical instances with a particularized and closed type of dynamics of functioning and programming. In this case, thinking about social systems or institutions implies thinking on a technical-logical structure at least in a strong sense: that means comprehending institutions as a set of formal, impartial and procedural rules, practices and actors with no political constitution and legitimacy. In a strong way, therefore, institutions are technical-logical structures that are not political, that cannot be intervened, framed and legitimized by political-normative principles, nor streamlined by political-normative subjects and practices. As a consequence, they must accept the fact that political reformism cannot change the self-referential internal organization, legitimation and evolution of social systems, conceiving social rights and institutional policies as based purely and simply on meritocracy. In fact, if social systems are technical-logical structures with internal dynamics of functioning and programming, 
and if they only work well on the basis of these internal technical-logical grounding and dynamics, then it is such self-referentiality and self-subsistence that define what is important and possible for the constitution, legitimation and evolution of each social system, which means that political praxis and social normativity cannot substitute for the technical-logical structuration of social systems. Only an indirect intervention could be an alternative to the pathology and crisis of social systems. Here again social rights and public policies only acquire sense by fomenting meritocracy, by protecting individuals against the dynamics and pathologies of social systems without changing the technical-logical and closed constitution of these; there is not an alternative project of social constitution, of political reformism, because technical-logical social systems cannot be conceived and transformed by politics - consequentially, political praxis and social normativity become minimalist, subsumed to the self-referentiality, selfsubsistence, endogeny and closure of social systems, i.e. to their technical-logical, nonpolitical and non-normative constitution, legitimation and evolution.

\section{SYSTEMIC THEORY, MERITOCRACY AND POLITICS: THE LIBERAL POLITICAL UNDERSTANDING OF WESTERN MODERNIZATION}

Contemporary political theory - represented by authors such as Ludwig von Mises, Friedrich August von Hayek, Milton Friedman, Robert Nozick, John Rawls, Jürgen Habermas, and Anthony Giddens - is directly or indirectly very based on two intertwined and interdependent points, namely: systemic theory regarding institutional structuring, and meritocracy as basis for social stratification. Western modernization, which is the philosophical-sociological background of those political theories, starts or emerges as a process of systemic institutional differentiation and autonomization of closed and particular social systems or institutions, especially the capitalist market and the bureaucratic-administrative State. These systemic institutions are a self-referential and self-subsistent complex of norms and practices that are basically independent with regard to the normative social context. They have particular and autonomized dynamics of functioning and programming along the time, which means that their process - in terms of functioning, programming and managing, in the moment they are particularized and very internal ones - assumes a technical and logical sense that is not political or normative, but fundamentally instrumental. Indeed, Western modernization - from a systemic perspective - leads to the institutional enclosure (particularly in the legitimation and constitution of the State and the capitalist market) that can be defined as a form of strong institutionalism regarding to the constitution, legitimation and evolution of social systems over time. The strong institutionalism of systemic theory means that the social systems themselves can monopolize and streamline their own structuring and development throughout time via their separation and autonomization concerning their normative-political dependence on society and on the political constitution in which they are inserted and linked. In other terms, systemic institutional legitimation and evolution are self-referential processes in relation to social normativity and political praxis, so they can evolve and stabilize themselves exclusively via their internal dynamics, norms, practices and authorized legal staff. Social systems are elements of a complete society, but they are particularized ones and have proper dynamics, norms and practices that are not the same as political praxis and social normativity. In consequence, social systems are independent fields of society, i.e. they cannot be associated or reduced to a notion of society as a macro structure or as a macro subject - society is a summation of many particular and closed social systems or 
institutions, each one of them very particularized and autonomous regarding the rest of society, and each one of them is constituted on a technical-logical basis that is nonpolitical and non-normative. An effective society does not exist really; it only exists by that summation of particular social systems and individuals. This is the starting point in order to understand and to ground Western modernization's social systems and institutions in liberal theories (see Mises, 2010; Hayek, 2013, 2006, 1995, 1987; Friedman, 1985; Nozick, 1991; Rawls, 2000, 2003; Habermas, 2012a, 2012b, 2003a, 2003b, 2002, 1997; Giddens, 1996, 2000, 2001).

A very interesting aspect of the systemic theory is the individualization of the legitimation, constitution and evolution of social systems, i.e. the systemic separation and autonomization regarding the social normativity and political praxis on which they are based. Consequentially, institutions appear always like a private world, like a very technical and logical instance that is non-political and non-normative, as previously said. Such an individualized and private world puts an unsurpassable normativepolitical barrier against notions of social normativity and political praxis that intend to link social systems' constitution, legitimation and evolution with the reproduction and evolution of society as a whole, also with the social-political subjects: the barrier is exactly the individualization of the social system based on a very particular technicallogical constitution, legitimation and evolution, which cannot be linked anymore with the social and political contexts and subjects from which it emerged. The basic consequence of systemic theory, therefore, is both the strong institutional individuality or singularity of each institution regarding the sociopolitical context, and the strong institutionalism concerning the self-constitution, self-legitimation and self-evolution of each social system throughout time, which imply the systemic depoliticization and enclosure in relation to alien principles, practices and social-political actors. The process of systemic constitution, legitimation and evolution is always internal, i.e. centralized and monopolized by the institution itself and its self-authorized legal staff. Systemic constitution, legitimation and evolution is not a democratic concern, as it does not allow a democratic political praxis from outside to inside; in the same way, systemic institutional structuration is strongly separate from the social sphere and from democratic political praxis, because of its individualization, which differentiates and autonomizes it in relation to society as a macro and interdependent structural context and systemic institutions only work through technical-logical dynamics, not from normative-political praxis.

The most impressive and impactful aspect of systemic theory is its association between the individualization of social systems and the strong institutionalism regarding the systemic institutional legitimation. First, each social system emerges and consolidates itself as a very particularized and individualized field of technical-logical, non-political and non-normative norms, practices, procedures and actors that monopolizes and centralizes the legitimation and the evolution of its very own field, becoming in fact the very field that it monopolizes and centralizes. Such individualization means also that there are not external instruments, practices and theoretical-political concepts or social-political actors to understand, to frame and to orientate the internal dynamics of the social system. These internal dynamics are selfreferential and autonomous, totally different with regard to alien contexts, subjects, practices, and norms, which makes the social system independent from the social context in which it is raised, as it becomes autonomous and closed regarding political interventions and normative framings. Second - as a consequence of that individualization of each social system and of its differentiation from the rest of society -, only the social system itself has legitimity to ground, streamline and orientate its own 
field of action throughout time, which leads to the strong institutionalism regarding the systemic constitution, legitimation and evolution of institutions. Here again, systemic institutions become independent and closed in relation to democratic political praxis and to a binding notion of social normativity, centralizing and monopolizing their internal, closed and technical constitution, legitimation and evolution, as rejecting political-normative framing - that is the meaning of the strong institutionalism, and its consequence is the fact that the technical staff of institutions, and only it, has legitimity to manage systemic values, practices and relations.

That is the liberal political comprehension of Western modernization, and it is assumed - with some variations, of course - by very different theoretical-political positions, such as the ones of Ludwig von Mises, Friedrich August von Hayek, Milton Friedman, Robert Nozick, John Rawls, Jürgen Habermas and Anthony Giddens, even if it is stronger in the first three than in the last ones. Their starting point is exactly the systemic self-differentiation, autonomization and self-referentiality of institutions as the basic aspect of Western modernization, which means that modern social systems are technical-logical instances that are very particularized, autonomous, self-referential and self-subsisting regarding political praxis and social normativity, which puts down the classical Marxian notion of society as a normative-political totality and of the social classes as a super-dimensioned political subjects. From now on, we have - when we think on Western modernization and its correlative political possibilities - the centrality of the technical-logical social systems and the individualization of the political subjects. From here onward modern societies' politics, economic constitution, status quo, State, public policies etc. are streamlined and legitimized. As a consequence, democratic political institutions, democratic political praxis and social normativity are constructed from such systemic understanding of Western modernization, which implies the fact that systemic individualization and strong institutionalism have become the methodological, normative and political criteria for the evaluation (and limitation) of all political projects, based on an interdependence and intertwining between social systems, political praxis and social normativity. Such interdependence leads to the necessity of a normative-political legitimation of the constitution and evolution of social systems, which are affirmed as linked to social reproduction, as strongly influencing the status quo, the social stratification and the distribution of economicpolitical powers. Contrarily to that, the individualization and strong institutionalism of social systems - i.e. the moment social systems are closed and particularized regarding political praxis and social normativity- disconnect them from their social roots, relieving them of the need to publicly, politically and normatively justify their internal structuration and evolution: social systems can assume a technical-logical explanation and foundation, based on meritocracy. In other words, a technical-logical constitution of social systems leads to their depoliticization and non-normative constitution, so social systems become self-referential and self-subsisting, closing themselves to political praxis based on social normativity. Social systems become basically an internal procedural way, practice and norms, centralized and streamlined by their own selfauthorized elites and technicians and performed in a technical-logical sense - economy for capitalists-economists, institutional politics for political parties and technicians etc.

Such situation of systemic individualization and strong institutionalism - which leads to the depoliticization of the systemic institutions, to their disconnection in relation to the social sphere and to the political praxis - can be perceived in a very pungent sense and range in the conservative political liberalism of Mises, Hayek, Friedman and Nozick. Indeed, the starting point of such conservative liberalism is the fact that there is not a society as a macro subject or as a macro structure with a core 
from which all social dynamics and social evolution are streamlined, defining status $q u o$ and the distribution of different kinds of social, political, cultural, and economic powers. Furthermore, there are not super social subjects, as social classes, but only individuals. In this sense, society is basically a summation of all particular individuals, each one of them with a very proper sense, practice and purpose, which are not the same as others'. Therefore the starting point of conservative liberalism is triple: there are not social institutions or structures from which social mobility is performed and defined; there are not social classes from which social dynamics and political context are streamlined; and there are only individuals, each one of them very particularized in relation to other individuals. Consequentially, Mises, Hayek, Friedman and Nozick speak about a spontaneous evolution of the society, which signifies the fact that such evolution - against left-wing proposals and understandings based on political interventionism and centralization - is not a matter of social and political programming, as if it were a conscious type of praxis that could be assumed and managed by central political institutions (like a Welfare State) while being, however, just a result of individual actions without an intentional consciousness of all social evolution. Each individual searches for their own personal interest, associating themselves with other individuals through their work, offering their abilities in exchange for goods of desire. The most special place for such social evolution and individual action is the market. The market is also a spontaneous arena that is not politically and normatively raised and linked to a notion of society as macro structure or as macro subject. It is not programmable or directed politically, nor normatively framed, because it is characterized exactly by such individualization both of institutional constitution and legitimation, and of social subjects. The market evolves by individual and selfish actions, i.e. by spontaneous dynamics and actions, establishing cultural practices, legal rules, and political institutions. That is the secret of Western modernization: economic spontaneity, self-referentiality and self-subsistence that generate socially binding institutions, rules, and cultural practices, an spontaneous evolution that is constructed over time by the work of the individual through the market, not by a macro political subject and a messianic political praxis. Against the left and its notions of a social totality and of social classes, conservative liberalism insists on such spontaneity and methodological individualism as the basis for social evolution and institutional grounding (see Mises, 2010, p. 57-101, p. 185-193, p. 315-388; Hayek, 1948, 01-32; 2013, p. 462-485, p. 488-507; Friedman, 32-108; Nozick, 1991, 16-78).

So it is not possible to make normative claims (like social justice) to the market, as it is not possible to perform political praxis inside it, for many reasons: first, it is not the same as other social fields - i.e. market is a particular field with particular rules, practices and subjects, and it has very internal dynamics of functioning and programming -; second, it is a spontaneous field based on individual action, on individual meritocracy; third, status quo is defined exclusively by meritocracy, not by the market as a macro structure or as a result of class struggles; fourth, the market is fundamentally a spontaneity, a non-power political speech, in the sense that there are not central and institutional rules and super political subjects that define all economic results and the distribution of the economic power - these economic results and the distribution of economic power are defined by individual meritocracy. In consequence, the market is individualized from the rest of the society and conceived as a technical field that depends only on meritocracy to evolve over time and to distribute the social goods according to the merit of each individual. As a spontaneous field, it cannot be guided and framed politically. Similarly, the distribution of social goods cannot be defined by a fanciful notion of social normativity or social justice, because it violates 
meritocracy - which is the unique normative basis of market constitution and evolution over time society as totality does not exist, according to conservative liberalism, so there are no collective and institutional responsibilities like e.g. social justice). Social justice is, according to Hayek, a mirage because of the fact that it is based on two mistakes: first, the notion of market as a macro structure and as a political result of class struggle; and the links of the market with political institutions and social normativity the market is in fact a particularized sphere that is spontaneous and non-structural (different from political institutions and political practices) and determined only by meritocracy (see Mises, 2010, p. 35-55, p. 815-837, p. 941-965; Hayek, 2013, p. 226238; 2006, p. 90-96; 1995, p. 49-72; Friedman, 1985, p. 21-143; Nozick, 1991, 14-88, p. 110-178).

What is important to conservative political liberalism is the fact that the market is conceived in a non-political and non-normative perspective, and in five ways: first, the market is a technical-logical social system, in the sense that it is not constituted, defined and legitimized from a political-normative standpoint; second, as a consequence, it cannot be framed and intervened from political-normative principles and praxis; third, it is not performed or defined from political-normative praxis assumed by macro social classes, but by very individualized selfish individuals, which means no moral-political basis and obligations about their relationships to one another over time; fourth, a juridical contract is the only principle and relationship on which economic relations are grounded and streamlined, and that means reciprocal juridical duties and obligations, but not a moral-political debt by which institutions must intervene and orientate economic dynamic and constitution; five, the market as a technical-logical social system presupposes basically its spontaneity, its laissez-faire, and meritocracy as a strategic individual capability regulated by a juridical contract. Thus from here emerges a model of economic social system that is self-referential and self-subsisting, spontaneous and non-structural (not managed by central powers and subjects, as are social classes and political dynamics), and characterized by individualized social actors (not by social classes). The market has no central dynamics, or central powers, or macro social classes, but fundamentally a type of technical-logical dynamics streamlined by individual strategic actions that are regulated by a juridical contract, assuming a non-political and non-normative constitution and foundation - that is the reason why Hayek denies the political-normative idea of the market as a selfreferential and self-subsisting social system, when he calls social justice as a mirage, because it presupposes a political-normative foundation of the market, i.e. its dependence on and linking with society as a normative-political totality (but market is a non-structural sphere performed by individual actions which are non-structural too).

We conceive conservative liberalism as leading to the naturalization and to the depoliticization of social inequalities and social stratification due to the following reasons: it individualizes market's constitution, legitimation and evolution, conceiving it as a spontaneous field that is totally different from political praxis and from a notion of social normativity; through the notion of meritocracy as basis of economic constitution and legitimation, conservative liberalism depoliticizes the structuring and grounding of the market, naturalizing methodological individualism as the fundamental principle of constitution and of legitimation of economic dynamics; and it denies the fact that the market is a macro structure defined by the confrontations between social classes, i.e. politically and normatively constituted. Such individualization, autonomization and self-referentiality of the market conducts to the economic enclosure concerning political praxis and social normativity, in the sense that the central problem (to conservative liberalism) is the political-normative intromission and framing of the 
internal, self-subsisting and self-referential technical-logical constitution and legitimation of the market, destroying its spontaneity and meritocracy as bases of the dynamics of the economic field. So the self-referentiality, individualization and spontaneity of the market must be protected against politics and social normativity substantial political praxis within social systems, according to Hayek, is the road to serfdom, given the fact that it denies individual mobility and meritocracy from the centrality of political institutions and their intervention into economy and central management of social life (see Hayek, 2013, p. 238-261; 1987, p. 17-91; Friedman, 1985, p. 146-198).

As we said above, John Rawls, Jürgen Habermas and Anthony Giddens share a similar comprehension of Western modernization that is proper to conservative liberalism. In other words, their epistemological-political starting point is the understanding of Western modernization as a process of systemic institutional differentiation, autonomization and self-referentiality, particularly due to the fact that the capitalist economy and the bureaucratic-administrative State emerge and consolidate themselves as individualized fields of the social world, independent from it, remote in relation to it, characterized by a technical-logical constitution, legitimation and evolution that oppose the normative structuring and grounding of the lifeworld. Of course, the main consequences of Rawls', Habermas' and Giddens's thought is not the same as Von Mises', Hayek', Friedman' and Nozick's, but such theoretical-political consequences are not too distant from these intellectuals. Indeed, the idea of modernization as a process of systemic institutional self-differentiation, autonomization, self-referentiality and self-subsistence has a shared basis with conservative liberalism: the individualization, differentiation and closure of each social system regarding their social context, each becoming a technical-logical, institution, matter and sphere. Here, each social system - especially the market and the State emerges and consolidates itself based on a process of individualization and specialization with regard to their environment, which means that each social system differentiates itself from the surrounding world, becoming a private field of social life, with its own rules, practices, procedures and legal actors that legitimize from inside its own constitution, grounding and evolution over time. In first place, therefore, Rawls, Habermas and Giddens accept the conservative liberalism's starting point, which is the autonomization, individualization and closure of State and market in relation to social normativity and democratic political praxis (see Rawls, 2000, §§10-19, p. 57-125; 2003, §04, p. 13-19; Habermas, 2012a, p. 296, p. 383-384, and p. 387-392; 2012b, p. 305 and p. 316; 2002, p. 04; 2003a, p. 61, and p. 190; 2003b, p. 105-106; 1997, p. 163; Giddens, 1996, p. 93-102, and p. 175; 2000, p. 122-123, p. 127, and p. 137-138; 2001, p. 46, p. 78, and p. 88).

Indeed, there is a very intrinsic linking among the New Left between systemic theory and institutionalism. Firstly, as I said above, the understanding of Western modernization as a process of self-differentiation, autonomization, self-referentiality and self-subsistence of each social system is the theoretical-political basis, directly or indirectly, for the analysis of Western modernization by the aforementioned intellectuals, which means the centrality of technical, non-political, non-normative and closed institutions as the central aspect, condition and movement of Western modernization. That means the technical-logical sense of the institutions, i.e. their nonpolitical and non-normative functioning and programing from very internal procedures, practices and norms assumed and centralized by an institutional self-authorized community of elites and specialists. Hence, here, a theoretical-political analysis that is purely normative is not capable of framing the phenomenon of Western modernization, 
as direct political praxis from civil society to institutions has no legitimacy to frame and change the technical-logical, self-referential and self-subsistent functioning and programming of these institutions. It is necessary an institutionalist theory and practice in order to frame and to orientate institutional transformations, as to understand them objectively - and that is the central intuition and leitmotiv of the New Left. Such institutionalist theory is characterized by the fact that the most central subject of analysis of Western modernization is the social systems or institutions themselves, and not the social classes, not the political subjects. That defines the entirety of the theoretical-political dynamics of the New Left, in the sense that it has a very institutionalist role and core characterized by the theoretical-political centrality of institutions or social systems in terms of understanding of the social constitution, legitimation and evolution over time. Indeed, the central subject of Western modernization is - according to Rawls, Habermas and Giddens - the institutions themselves as sets of formal, impartial and neutral procedures, practices, norms and legal staff that centralize, legitimize and streamline each field of social reproduction. The political role and core of the institutions, which are determined by the class struggles for social-political hegemony, are left aside; they are not taken into account as basis for the theoretical-political assumptions on Western modernization. Institutions appear like impartial, neutral and formal structures with a technical-logical functioning and programming, beyond the carnality and the politicity of social life, therefore beyond the class struggles for hegemony that determine the meaning and the way of institutional constitution, legitimation and evolution.

The intrinsic linking - by the New Left - between systemic theory and institutionalism, secondly, leads to the fact that any social-political transformation is performed from the theoretical centrality and technical-logical functioning of the social systems, due to the fact that the theoretical-political analysis of the New Left focuses on the institutional field, as it presupposes that institutions are social subjects imposed on social classes, on political subjects. The theoretical-political centrality of the institutions - from the perspective of systems theory - means that institutions cannot be understood nor framed by normative-political principles and subjects, as they cannot be situated on the political-normative soil of contemporary social life, on the political-normative soil of class struggle. In other words, institutions are part of a society as a whole, but they cannot be subsumed to this totality, by this totality, as they cannot be reduced to any social principle and political subject. So, the understanding of Western modernization as a process of institutional self-differentiation, self-referentiality and self-subsistence means that any social system - although it is part of a society as macrostructure - has an individualized and particularized constitution that is characterized by a very specific technical-logical functioning and programming. Contrary to traditional societies which are defined as normative-political totalities very intertwined in their parts -, Western modernization appears in the New Left as a process of consolidation of different and autonomous institutions, regarding the social world and the normativepolitical constitution of the society. From now on, a sociological and political theory must accept the fact that the theoretical analysis and political praxis are defined and even legitimized because of the technical-logical constitution, legitimation and evolution of social systems - because of the fact that, therefore, institutions are the central subjects of society, as they are the central subjects of their proper functioning and programming throughout time. The social struggles between opposing social classes strongly disappear from theoretical-political considerations, given the centrality of the impartial, neutral and formal institutions with a technical-logical basis of action. Through their autonomization of social life, through their self-referentiality and self- 
subsistence, social systems impose a very strong barrier between - on one side - their technical-logical functioning and programming, and - on the other - political-normative subjects and practices, as if social systems were not a political-normative world defined by class belonging and clashes, as if they were overlapped to social classes and their political struggles for hegemony, and finally as if they were really independent on society as a normative-political totality.

What consequences arise from here? They are quadruple: (a) the social systems of Western modernization - the moment they are characterized by systemic institutional autonomization and enclosure regarding democratic politics and social normativity are determined basically by internal procedures, practices and authorized people, which means that common people have no legitimacy to frame and to decide about systemic institutional dynamics; (b) a kind of strong institutionalism emerges from such systemic institutional comprehension of the constitution, legitimation and evolution of the market and State, i.e. a model of self-subsistent and self-referential systemic institution admits only its internal proceduralism as the basis for its legitimation and dynamics throughout time - internal proceduralism gives the last and decisive word concerning internal institutional constitution and legitimation; (c) systemic institutions are greatly depoliticized, becoming a non-normative structure - becoming just technical and logical instances -, and that leads to the refusal of an external political and normative intervention inside social systems, because they have particular and individualized logics of functioning and programming that are non-political and nonnormative, only technical; (d) the tension between system and lifeworld, in Habermas' words, cannot be resolved by interventive political praxis that is based on a notion of social normativity, because of the systemic enclosure, self-referentiality and selfsubsistence concerning exactly political praxis and social normativity.

Political liberalism (Rawls), critical social theory (Habermas) and the Third Way (Giddens) try to conciliate normative claims, political praxis and this systemic institutional comprehension of Western modernization through (according to them) a theoretical-political dualism that divides modern societies in social normativity and systemic institutions. On the one hand, society is streamlined for a shared notion of social normativity that is the basis for evaluating different individual and group vindications; on the other hand, society is a summation of multiple individualized and autonomous social systems that have specific and closed dynamics of functioning and programming. Democratic politics is in the middle of these two sides: it must distribute social goods based on such notion of social normativity and at the same time organize social systems according to this democratic social normativity. How does democratic politics do that? It cannot intervene directly in the internal, self-referential and selfsubsisting constitution of social systems, because they are technical and logical spheres, not political or normative structures; it means that political praxis based on social normativity cannot substitute for the technical-logical functioning and programming of social systems. So democratic politics makes such conciliation through an indirect intervention (see Habermas, 2003b, p. 148; Giddens, 2000, p. 109-127), i.e. through a political reformism regarding the constitution and action of the State, regardless of the constitution and dynamics of the market: this indirect political reformism maintains the self-referentiality, self-subsistence and enclosure of the market through its stabilization against accumulation crises and deficits of social consumerism, and through an institutional offer of social rights paid by the taxes of workers and capitalists (see Esping-Andersen, 1999, 2003; Piketty, 2014). The basic problem here is exactly the individualization of systemic institutions, which leads to their enclosure, selfreferentiality and separation in relation to their social roots and political constitution. In 
other words, Rawls, Habermas and Giddens - when they assume the systemic institutional comprehension of Western modernization (the same as conservative liberalism) - cannot ground a critical theoretical-political perspective to face the current crisis of Western modernization, which is caused by the systemic comprehension of it. The use of the lifeworld - as a notion of social normativity capable of controlling and limiting systemic pathologies - cannot overcome the fact that the systemic institutional understanding of Western modernization depoliticizes institutional autonomization and self-referentiality in relation to democratic politics and to social normativity, isolating the market from political democracy and social normativity through its individualization regarding the rest of the society. Here, an alternative theoreticalpolitical way is very necessary to a critical social theory.

Now, how does systemic theory isolate the constitution, legitimation and evolution of the market from political democracy and social normativity? What consequences arise from here? First, systemic theory isolates the constitution, legitimation and evolution of the market in relation to political praxis by technicizing its functioning and programming, by conceiving the market as a technical-logical structure that is non-political and non-normative. As we said above - also as Parsons, Luhmann and Habermas recognize -, systemic theory conceives society as a superstructure that is constituted by particularized and individualized social systems or institutions, each one of them with a very specific technical-logical constitution and functioning: hence systemic theory isolates the social systems by individualizing and technicizing them with regard to politics and social normativity, and, in fact, politics becomes also a social system among others, with the same status as others (see Habermas, 2003b, p. 25). The first thing we must take into account in theoreticalpolitical terms, therefore, is the fact that Western modernization only can be understood and framed from the centrality of these technical-logical, self-referential and selfsubsisting social systems. Here, the market works well given its technicality, impartiality and superimposition on political-normative praxis and political subjects. A technical-logical functioning of the market and the political-normative constitution of civil society cannot be mixed or associated - contemporary political theory starts from here and that defines its type of political praxis regarding social systems. Now, the consequences that arise from here are basically two. First, Rawls', Habermas' and Giddens's intention to ground a correlation between normative theory and institutional (or systemic) theory in order to frame and to orientate the path of Western modernization - so as to cure the pathologies of Western modernization - are doomed to failure, because - despite the power of political praxis and social normativity - the technical-logical constitution of social systems can always affirm its specificity, selfreferentiality and self-subsistence regarding political praxis and social normativity. That is, the systemic constitution of modern institutions means their non-normative and nonpolitical structuring and functioning, which lead to the depoliticization of social systems. As a consequence, the democratic political praxis can only frame the social systems through an indirect intervention; it never can violate their technical-logical constitution and grounding, or their self-referentiality and self-subsistence (see Habermas, 1997, p. 163; 2003b, p. 147-148). Second, the correlation between normative theory and institutional-systemic theory is not capable of facing the conservatism regarding the understanding of Western modernization - that is the basic theoretical-political purpose of the New Left - because Rawls, Habermas and Giddens concede theoretical-political centrality to social systems as sets of impartial, neutral and formal procedures, practices and legal staffs that are greatly non-political and nonnormative instances and subjects. As a consequence, social systems appear 
fundamentally as technical-logical structures and subjects, basically depoliticized. The social struggles between conflicting social classes - i.e. the political subjects of the civil society - do not acquire theoretical-political importance at all regarding the understanding and the framing of Western modernization. In fact, Western modernization is a process in which institutions or social systems - as impartial, neutral and formal structures and subjects with no carnality and politicity - emerge and develop themselves, becoming hegemonic politically speaking and separating themselves in relation to civil society. But where are the political subjects, the social classes that streamline - through their social-political clashes - the hegemonic way of the Western modernization in general and the definition of social systems in particular? These political subjects, these political classes do not appear in Rawls', Habermas' and Giddens's understanding of Western modernization: as a consequence, self-subsisting, self-referential and autonomous technical-logical institutions or social systems with no politicity/carnality become the unpolitical subjects, dynamics and arenas of their proper constitution and societal evolution, so that political praxis become dependent on the technical-logical constitution of social systems and on the correlative barrier that is instituted between them and the normative lifeworld. Here, a radical democratic political theory has no future and influence, because politics is restrained by the technical-logical social systems, which are also impersonal, dissociated from social subjects and class struggles.

\section{BEYOND SYSTEMIC THEORY AND MERITOCRACY IN POLITICS}

The moment that the New Left uses the systemic theory in order to understand and to frame the contemporary process of Western modernization, it must accept directly or indirectly the centrality of the technical-logical, non-political and nonnormative constitution, legitimation and evolution of these social systems, so that their self-referential, self-subsisting and technical-logical functioning and programming remain untouched by politics. Now, how is it possible - as Rawls, Habermas and Giddens intend - to ground a radical democratic political theory from the perspective of systems theory, from the perspective of the centrality of institutions and their impartial, neutral and formal proceduralism? Technical-logical social systems or institutions have no carnality, no politicity, so how can they be framed and changed by a political theory that is not technical-logical one, but instead a very normative one? Yet technical-logical social systems or institutions have as their basis of functioning and programming very formal, impartial and neutral procedures, practices, codes and legal staff: so how can social movements and citizen initiatives - based on political-normative praxis - discuss and influence the structures, dynamics and ways through which social systems and political institutions must act? In both cases, social systems can close themselves in relation to an inclusive and participative democratic political praxis by emphasizing their technical-logical constitution, their non-political and non-normative functioning and programming, which means also that only a self-authorized legal staff that is internal to the social systems (and that works based on a technical-logical procedure and code) has legitimity to manage them in their internal proceduralism and technicallogical structuration. Thus, if political democracy and social justice are possible on the basis of systems theory, they are possible beyond the social systems themselves, because of their self-referentiality and self-subsistence based on a technical-logical constitution, legitimation and evolution that is differentiated and autonomized with regard to democratic political praxis and social criticism. 
Now, if we follow the use of systemic theory by the New Left - in correlation to a normative theory - in order to understand and to frame the process of Western modernization and, as consequence, to ground a model of radical political democracy for current times, then we must conclude that the only distributive justice possible (according to systemic theory) is exactly meritocracy, so that the technical-logical constitution of social systems remains untouched and unchanged by politics, becoming in truth the center from which political institutions acquire meaning and action over time. Indeed, in this case, a notion of social justice that is reached by democratic inclusive and participative political praxis cannot intervene and change the technicallogical structuration, functioning and programming of social systems. Its only basis is the fostering of meritocracy as a way and form of including individuals in the systemic dynamics and logic of evolution. Meritocracy becomes the reason for being of a political reformism that is based on the systemic understanding of Western modernization. Thus, here, the political praxis of citizens and social movements, as the social roots of political institutions, acquire basically two purposes: to guarantee the self-referentiality and the self-subsistence of social systems - as conservative liberalism always argued - through the centralization of instruments and of the use of legitimized violence, and through the application of commutative justice; and to offer a set of individual rights and social goods through which meritocracy is possible as basis for the status quo and for the dynamics and functioning of the market. The centrality of meritocracy in systems theory means in fact the weakening and the delegitimation of political praxis and political institutions as bases for societal organization, grounding and evolution, as bases for the constitution and legitimation of social systems, through the very centrality of the technical-logical, non-political and non-normative social systems that have become strongly particularized regarding society as a whole and closed to the political framing of institutions. Another theoretical-political perspective to the systems theory is necessary for an effective political-normative understanding and framing of Western modernization.

Such alternative theoretical-political view has as its basis the recovery and the renewal of the notion of society as a normative-political totality that is streamlined by the struggles between social classes. This concept of society as a normative-political totality has not the meaning of a mechanical summation or juxtaposition of individual and self-referential parts, as if each part had a meaning exclusively singular and closed in relation to other parts. A normative-political society is not the same as the systemic notion of society as a summation of particular technical-logical social systems or institutions and apolitical individuals - as it is assumed by contemporary political liberalism, both in the right and in the left (with their specific differences, of course). In our proposal, therefore, a notion of society as a normative macro structure streamlined by social classes and their struggles for political hegemony intends to overcome the systemic institutional individualization and depoliticization of the social systems, i.e. their enclosure, self-subsistence and self-referentiality with regard to democratic politics and social normativity. This notion of society as a normative-political macro structure links all social spheres in a reciprocal movement determining both macro situations and even particular dynamics, meaning that the effects of systemic institutions are not particularized and related only to the internal field of each social system - as they are not technical-logical procedures, practices and codes without political-normative meaning, links and consequences.

Contrary to that, the forces, effects and decisions of social systems strongly influence general aspects of social evolution and constitution, which implies the politicization of social systems, as with their framing of a binding notion of social 
normativity that can be used by political institutions to orientate and to regulate economic structuration and legitimation: it can be used also by the struggles, vindications and claims of social movements. Above all, such a notion of society as a normative-political macro structure aims to deconstruct the liberal theoretical-political starting point, i.e. the conceiving of Western modernization as a process of systemic institutional self-differentiation, self-referentiality, self-subsistence and autonomization of technical-logical institutions. As we argued above, this liberal understanding of Western modernization leads to the systemic institutional depoliticization, closure and complete individualization of social systems regarding the rest of the society. It leads also to a mechanical notion of society as juxtaposition of individual parts, which means that (according to liberal politics) individualized social systems not only have very proper and closed dynamics, but such individualized dynamics have solely internal effects and consequences - therefore not affecting and influencing the rest of the society. Besides, the liberal political comprehension of the Western modernization understands systemic institutional structuration and constitution based on a technical and logical meaning that is non-political and non-normative, so that the functioning and programming of social systems are basically an internal procedure that is centralized and managed by a core of specialists and elites that, due to their technical-logical specialization, become the only responsible agents for the legitimation of social systems and their evolution along the time. Here, democratic politics and social normativity have no legitimity to intervene in social systems, but only a mixture of technocracy and meritocracy. It means also the fact that social movements and citizen initiatives have not an active role with regard to the internal constitution, legitimation and evolution of institutions, which become a matter for the technicians and elites of institutions.

Starting from the notion of society as a normative-political totality or macro structure defined by class struggles and by macro institutional actions, we can conclude two important theoretical-political ideas. First, there is not a systemic institutional selfreferentiality, self-subsistence, individualization and technicization, but a very direct institutional politicization both of internal institutional constitution and legitimation, and of its external relations with society as a whole and, of course, with the social classes, with the political subjects. Thus, there is not any sense to the the liberal attempt to depoliticize and to individualize the constitution, legitimation and evolution of social systems, denying the political-normative framing of systemic institutions; also, there is not any sense either to the liberal idea of a technical-logical constitution, legitimation and evolution of the social systems: i.e. their non-political and non-normative structuration, functioning and programming are false presuppositions that intend basically the depoliticization and the non-normative understanding of the social systems - the New Left -the moment it uses such systemic notion of Western modernization leads also to the systemic institutional depoliticization and, as consequence, to the weakening of radical democratic political praxis. Therefore, if social systems are not individualized ones - if they are macro institutions with macro effects and consequences, and also streamlined by class struggles -, then they are fundamentally politicized, generating social expectations and, as we said above, macro effects and consequences that lead to their framing through such notion of social normativity, through inclusive and participative democratic political praxis. The technical and logical structuring, constitution and legitimation of systemic institutions are a fallacy without any basis in any economic, sociological or philosophical theory. The politicization and linking of social systems with a notion of society as a normativepolitical macro structure that has general effects and consequences, as super social actors, allow for institutional framing by democratic politics and social normativity: 
here we can speak rightfully of social justice, democratic political praxis and interventive politics. Here we can deny also the liberal spontaneous evolution of society and market, because both society and market are macro structures that have general effects and consequences, as well as super social actors (social classes and institutions) that streamline politically and normatively the route of evolution and the type of institutional structuring along the time.

Second, if systemic institutions (like the market) are not individualized ones - if they are not spontaneous ones -, then there is not an effective meritocracy that can define as a whole all social stratification and then the status quo: it cannot define the major tendencies in social stratification and social mobility, which are beyond such meritocracy. Indeed, if we analyze, for example, Thomas Piketty's Capital in the Twenty First Century, with its empirical researches regarding the continuity of social inequalities or regarding social mobility throughout history, we will perceive that social stratification and social mobility are streamlined and defined by the economic starting point or by the social-economic condition of the particular subjects (see Piketty, 2014; Hicks, 1999; Wacquant, 2001; Katz, 1989). The family condition, the educational and cultural resources and the sex, the gender and the color of skin are the normativepolitical basis for social stratification and social mobility. That is a fact of all contemporary democracies (of all societies, in truth): that is a fact from which contemporary social theory must start. Hence, economic constitution is the basis for the status quo, and not meritocracy. And such fact means that the most important factors in terms of status quo and social mobility are not individual meritocracy and market spontaneity, but the social and institutional conditions from which individuals and groups found a material, normative and political basis to develop themselves over time. Even here the institutional conditions and structuring define what kind of social constitution and social mobility individuals and groups will have over time.

The main question to us, currently, is exactly the hegemonic understanding of Western modernization. As we argued throughout this paper, the liberal comprehension of Western modernization from a systemic institutional perspective leads to the depoliticization and to the individualization of the constitution, legitimation, and evolution of social systems, putting meritocracy as the fundamental normative principle for the orientation of political reforms, social rights, and the status quo, and establishing the technical-logical, self-referential, self-subsistent and endogenous social systems themselves as the criteria for their internal functioning-programming, as the unsurpassable basis-barrier of-for politics. The individualization of social systems means their closure and technicization, i.e. their independence regarding democratic politics and social normativity. Here, again, only meritocracy - a consequence of systemic institutional depoliticization and individualization with regard to society as a whole - has legitimacy to define social evolution and individual mobility. However, such a notion is non-critical to a social theory, because it depends on a technicization of social institutions - the same way that it conducts to the depoliticization of these institutions -, as if all social dynamics were based on individual merit and on economical spontaneity, as if all social dynamics were fundamentally dependent on the self-referentiality and self-subsistence of social sytems in relation to politics and social normativity. Contrary to that, our point is that systemic institutional self-referentiality, self-subsistence and individualization cannot be defended or assumed without serious consequences to a critical social theory: systemic theory, the moment it individualizes and technicizes the structuration of social systems, depoliticizes them, so social theory and political praxis are not necessary here.

Our suggestion is to substitute the liberal notion of Western modernization based 
on systemic institutional theory with the notion of society as a normative-political totality. In this latter case, social institutions - like the capitalist market and the State are not individualized, enclosed and technical spheres with a very particularized proceduralism of norms, practices and legal actors that are totally different and even opposite to democratic politics and to social normativity. Similarly, our point enables the understanding of Western modernization not as a process of systemic autonomization, self-differentiation, self-subsistence and self-referentiality of technicallogical institutions in relation to the lifeworld, but exactly as the emergence of a new form of material production and social-cultural life based on the permanent attempt to separate social systems and lifeworld as a basic aspect of the Western capitalism. Indeed, the fundamental normative-political point of conservative liberalism is directly the understanding that the economic field of capitalism is individualized regarding the social and political spheres, as it is based on economic spontaneity and individual meritocracy, something that is antagonistic to politics and to social normativity. That reveals the true core of Western modernization: there is a permanent struggle related to the hegemonic comprehension of the relationships between economy, politics and social normativity, and that is the main question about Western modernization, especially for its victims: its direct politicization - it must be politicized. Here there is nothing technical or logical in question, as there is nothing non-political or individualized from social totality. Above all, our point allows for an alternative political-normative comprehension of the Western modernization that is opposed to the systemic theory and meritocracy of political liberalism. In this alternative point, Western modernization is firstly a political-normative question, defined by permanent theoretical-political clashes between conflicting social classes; in it, Western modernization is not defined by systemic institutional individualization and enclosure regarding democratic politics and social normativity, but by its very politicization and intrinsic linking between economy, politics and social normativity; and at last social inequalities and the status quo in modern societies only can be comprehended through such politicization, which means the refusal of systemic theory and meritocracy as bases for economic organization, political institutional structuration and social stratification.

A last word is important. It could seem a madness to put Rawls, Habermas and Giddens (as main representatives of the contemporary New Left) in the same theoretical position as conservative liberalism. However, they assume directly the fact that conservative liberalism has much to say in terms of understanding Western modernization. And, as we showed throughout the paper, they have a similar notion although with different conclusions - about this understanding of the process of Western modernization, namely the idea that Western modernization is a societalinstitutional process characterized by the emergence and consolidation of different social systems that are self-referential, self-subsisting and autonomous regarding political praxis and social normativity, marked by a technical-logical constitution, legitimation and evolution. Such a New Left theoretical-political standpoint, we repeat, is the same as the conservative liberal standpoint. Of course, as we also said above, the New Left tries to conciliate normative theory with institutional-systemic theory, by putting the development of social systems into the general sphere constituted by civil society or the lifeworld, which would lead, according to New Left, to the possibility of a political-normative framing of Western modernization in general and of social systems in particular. However, the strong separation between a normative-political sphere (civil society or lifeworld) and the technical-logical constitution of the social systems means that political praxis no longer has the power to impose a normativepolitical constitution, legitimation and evolution on social systems, so here social 
systems become the fundamental criteria to the praxis and vindications of politics and civil society, and not the contrary. In other words, the tutilization - by the New Left - of systemic theory in order to understand and to frame the process of Western modernization leads to the centrality of technical-logical social systems as the fundamental basis through which political praxis and social normativity - as political institutions - are defined and streamlined over time. Political praxis and social change, therefore - as a consequence of that New Left standpoint -, are beyond the constitution, legitimation and evolution of social systems, in the sense that political democracy and social justice cannot change the self-referentiality and self-subsistence of social systems, i.e. their technical-logical sense.

\section{REFERENCES}

BOLTANSKI, Luc \& CHIAPELLO, Ève. O novo espírito do capitalismo. São Paulo: Martins Fontes, 2009.

FRIEDMAN, Milton. Capitalismo e liberdade. Rio de Janeiro: Editora Artenova, 1985.

GIDDENS, Anthony. Para além da esquerda e da direita: o futuro da política radical. São Paulo: Editora da UNESP, 1996.

. A terceira via: reflexões sobre o impasse da social-democracia. Rio de Janeiro: Record, 2000 . . A terceira via e seus críticos. Rio de Janeiro: Record, 2001.

ESPING-ANDERSEN, Gosta. Social foundations of postindustrial economies. Oxford: Oxford University Press, 1999.

.Why we need a new Welfare State. Oxford: Oxford University Press, 2003.

HABERMAS, Jürgen. Teoria do agir comunicativo (Vol. I): racionalidade da ação e racionalização social. São Paulo: Martins Fontes, 2012a.

. Teoria do agir comunicativo (Vol. II): sobre a crítica da razão funcionalista. São Paulo: Martins Fontes, 2012b.

. Direito e democracia (Vol. I): entre facticidade e validade. Rio de Janeiro: Tempo Brasileiro, 2003a.

. Direito e democracia (Vol. II): entre facticidade e validade. Rio de Janeiro: Tempo Brasileiro, 2003b.

. O discurso filosófico da modernidade: doze lições. São Paulo: Martins Fontes, 2002.

Ensayos políticos. Barcelona: Ediciones Península, 1997.

HAYEK, Friedrich August von. Law, legislation and liberty: a new statement of the liberal principles of justice and political economy (3 vols.). London/NewYork: Routledge, 2013. . Arrogância fatal: os erros do socialismo. Porto Alegre: Editora Ortiz, 1995. Individualism and economic order. Chicago: The Chicago University Press, 1948.

" "The meaning of the Welfare State", p. 90-95. In: PIERSON, C.; CASTLES, F. G. (Eds.). The Welfare State reader. Cambridge: Polity Press, 2006.

. O Caminho de servidão. Rio de Janeiro: Instituto Liberal, 1987.

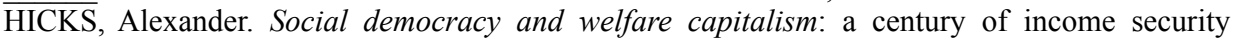
politics. Ithaca; London: Cornell University Press, 1999.

KATZ, M. B. The undeserving poor: from the war on poverty to the war on welfare. New York: Phanteon Books, 1989.

MISES, Ludwig von. Ação humana: um tratado de economia. São Paulo: Instituto Ludwig von Mises, 2010.

NOZICK, Robert. Anarquia, Estado e utopia. Rio de Janeiro: Zahar, 1991.

PIKETTY, Thomas. O capital no século XXI. Rio de Janeiro: Intrínseca, 2014.

RAWLS, John. Uma teoria da justiça. São Paulo: Martins Fontes, 2000. . Justiça como equidade: uma reformulação. São Paulo: Martins Fontes, 2003.

WACQUANT, Loïc. As prisões da miséria. Rio de Janeiro: Zahar Editor, 2001. 